\title{
The Level Understanding, Appreciation and Practice of Malay Language among Education Students in Public Universities
}

\author{
Zamri Mahamod, Ummu Taqiah Bahari \\ Faculty of Education, Universiti Kebangsaan Malaysia, Bangi, Malaysia \\ Email: d-zam@ukm.edu.my
}

How to cite this paper: Mahamod, Z., \& Bahari, U. T. (2017). The Level Understanding, Appreciation and Practice of Malay Language among Education Students in Public Universities. Creative Education, 8, 2109-2123.

https://doi.org/10.4236/ce.2017.813142

Received: April 26, 2017

Accepted: October 21, 2017

Published: October 24, 2017

Copyright $\odot 2017$ by authors and Scientific Research Publishing Inc. This work is licensed under the Creative Commons Attribution International License (CC BY 4.0).

http://creativecommons.org/licenses/by/4.0/

\begin{abstract}
This study aims to identify the level of understanding, appreciation and practice of Malay Language identity among students of education at five public universities in Malaysia. A total of 1000 students, that is 200 persons per a Public University ranked as Research University served as the respondents. Randomly selected respondents were studying in various educational programs in the Faculty of Education in Public University which UKM, UM, USM, UPM and UTM. Questionnaire was used for data collection. Instruments developed by researchers have a high level of validity and reliability which is 0.75 . Data were analyzed by descriptively and inferentially using the Statistical Package for Social Sciences (SPSS) version 23.0. The results showed that in general, education students of public universities still maintain their Malay identity. However, in terms of Malay language appreciation and practice it is at the level still remained identity. UM students have the lowest level of understanding, appreciation and practice of their Malay language. USM students are the student with the highest level of Malay language identity in all three aspects. The implication of this study is the university's emphasis on the mastery of written and spoken English language to some extent affects the level of understanding, appreciation and practice of the Malay language among education students of the Public University.
\end{abstract}

\section{Keywords}

Understanding, Appreciation, Practice, Malay Language Identity, Education Student

\section{Introduction}

Identity is dignity that describes personal characters of each nation or tribe. In- 
ternal strength (soul and feelings) consistency, perseverance and all things that mean robustness that fixed so strongly in them that cannot be contested is the foundation of identity. To produce faithful and united citizen, the strength of identity must be possessed by individuals, nations and tribes (Abdul Latiff, 2012). In the context of this research, in order to produce integrated individuals and make the country developed and free from the threat of globalization and other threats of today, the element of identity needs to be incorporated first in each prospective educator. This is because educators are individuals who will create and make more virtuous and strong identifiable human in order to develop the country.

Being a teacher desperately needs high identity. As an educator, personal values and identity are not just in terms of knowledge, but also religion, values, language, culture, unity, and national spirit. This is because in the 21st century, to produce a generation that has high morals and character is not a simple matter. It is important to carry out survey on the identity of education students so that the result of the findings will determine the government's plan to increase the level of identity among students.

Perhaps academically, they are brilliant, but how about their personality, especially their identity. This study is necessary because, as an agent of change, to what extent that these prospective teachers still embrace their identity or that their identity has been eroded. Is this prospective teacher have a thick level of understanding, appreciation and practice of education, eastern value, language, religion, culture, unity, and their nationalistic spirit? This is important because in order to produce a balanced prospective teacher physically, emotionally, spiritually and intellectually, they should have a strong identity.

\subsection{Problem Statement}

Education system in Malaysia is among the best in the world. The introduction of the Malaysian Education Development Plan 2013-2025 (Kementerian Pendidikan Malaysia, 2013) proved that Ministry of Education (MOE) is concerned about the importance of education among its citizens. Among the main points of emphasis and attention in the Blueprint 2013- 2025 is Shift 4: Transformation of Teaching as a Profession of Choice. In Shift 4, various initiatives are provided by the government, including the selection of prospective students to the Public University (Faculty of Education) or the Institute of Teacher Education Malaysia (IPGM). In the Blueprint plan book, the government has set that only the selected and excellent students in academic and co-curricular activities will be selected to enter the teaching profession. The question is, to what extent that the prospective teachers in public universities and IPGs really have the identity? Maybe academically, they are brilliant, but not in their character, especially their identity. Qualification tests that are held not necessarily be able to identify the high quality candidate teachers. For example, test 1: answering multiple-choice questions are more on the cognitive only. Test 2: interview only see at a glance their character, personality, know- 
ledge, understanding and other fields related to education. What about their identity? This cannot be measured in the evaluation and selection of prospective teachers to continue their studies at public universities or IPGM.

Studies on people's identity are not new. Identity means to strengthen public confidence in the system of beliefs adopted by the society which adheres to the religion, will not do bad things (Ismail, 2010). Why the question of identity among education students of RU Public University wanted to be studied? According to Mohd Yusoff et al. (2012), identity among young people today needs to be studied. As education students of the RU Public University represent the young generation, indeed, they also need to be studied. The reason for this is strengthened by the slogan that the teacher is an agent of change. As education students of RU Public University will mostly venture into teaching career, certainly they are regarded as the agents of change. This is very important because the RU Public University education students will be the next teacher trainee and then become a teacher. Thus, without a doubt the identity of the prospective teachers should be complete in terms of education, religion, values, language, culture, unity and the spirit of nationalism. If this matter is strong in the soul of the teacher, certainly the generations that are taught will be strong and balanced in every aspect.

Studies related to the identity have already been conducted by some researchers. For example, Ramlah (2005) studies how university students' understanding, appreciation and practice of the Rukun Negara. Ramlah's study found that despite significant, there have been leakages, reduction and fading of understanding, appreciation and practice of the Rukun Negara among university students in Malaysia. Mohd Yusof et al. (2012) for instance, study about university students' national identity. The findings showed that 54.6 percent of university students have strong identity. Study by Mohd Yusuf et al. is general, which includes all university students regardless of race. A study conducted by Hashim (2008) on the other hand studied the Malay identity whether they still maintained the identity or their Malay identity is faded. The result of research showed that the identity of many Malays are beginning to wear off in terms of value, but the identity in the aspects of religion, knowledge and educates are still remain. Hashim's study is more on the Malays only, but has multiple categories. A study conducted by Siti Sarah (2015) using approach of Hashim (2008) to build online measurement tools for Malay's Hati Budi to determine how Malays still maintain the identity or otherwise. Study by Siti Sarah is on the Malays, but the number of respondents was too small and did not reflect the real identity of the Malays.

The level of identity of education student in Public University needs to be studied. Previous studies have found that the identity of the Malays began to fade. Does the same thing apply to education students of the Public University which allegedly agents of change and will inherit the leadership of the country? Thus, the development of Public University education students' identity index can be 
used as a guide in the selection of future teachers so that the identity of these teachers will remain strong and intact without being influenced by the negative elements. As agents of change, indeed the future teachers will have a strong identity. Continuous efforts should be made to strengthen the identity of the education students of Public Universities.

In addition, the study of the identity among education students of Public University has never been studied by any researcher whether at Public Universities, Private Universities, IPGM or by any government institution. Most of the researches were done in the context of history, sociology, anthropology and religious. Not specific to education. For example, study by Ramlah (2005) viewed the historic aspect about Rukun Negara. Similarly, the study of Hashim (2008) and Siti Sarah (2015) are on language. Study by Mohd Yusof et al. (2012) was more towards the national identity of Malaysian. In other words, all the study are of general nature and none focused on the identity of the education students in Public University. Hence, it is necessary to make a study of the identity of the students in terms of education. The development of education student's identity index can help the MoE to identify prospective teachers who really have a powerful identity so that they are balanced with the National Education Philosophy.

\subsection{Study Aims and Objectives}

This study aims to identify the level of understanding, appreciation and practice of Malay language identity among education students in the Faculty of Education at five public universities, namely UKM, UPM, UM, USM and UTM. In particular, the objective of this study was to:

1) Are there differences in the level of Malay language identity among students of education stream in accordance with the five public universities studied?

2) Are there different levels of understanding, appreciation and practice of Malay language identity among education students in the five public universities studied?

\section{Methodology}

\subsection{Research Design}

This study used quantitative descriptive survey research through questionnaires to obtain information from Bachelor of Education students on their perceptions of their identity based on seven elements of identity. A total of 1000 undergraduate students of education stream in Faculty of Education from five Public University were selected through purposeful sampling. They consist of 200 students each university were selected as respondents.

\subsection{Research Instrument}

This study used questionnaires developed by members of the research team 
based on previous research instruments such as study of Salmah (2005), Mutsalim \& Jaffary (2014), Singh (2013), Tarmizi (2013), Mohd Isa et al. (2012) and Siti Rahimah et al. (2014) and a number of items designed by members of the research team. The questionnaire consists of two parts. Part A is to get the student demographics. Part B is to study the level of understanding, appreciation and practice of Malay language identity of the education stream students which contains 36 items.

The instrument is built using a 10-point Likert scale. This scale is taken and adapted based on the Malaysian Youth Index 2011 (IBM Ministry Youth and Sports, 2011). For the purposes of interpretation of the score, the measurement is divided into four stages. Based on the study IBM 2011, the less good index is on a score scale of 1 to 3 (faded identity), moderately good on a score scale of 4 to 5 (begin to fade identity), the good level scale is on a score scale of 6 to 8 (still remain identity) and the excellent level is on a score scale of 9 to 10 (permanent identity). The mean value was based on four scales as shown in Table 1.

Validity of the instrument was carried out by referring to three appointed experts evaluators of instruments for the expert validity. The initial instrument containing 36 items have been reviewed by the expert evaluators and some items were removed as advised by the experts. The Cronbach alpha analysis showed that the reliability is high (Piaw, 2012).

\subsection{Data Analysis}

Descriptive analysis was conducted using the mean value to see the level of identity index of the students. Data for each item in Part B were analyzed using SPSS. Descriptive statistical analysis was used to find the frequency, percentage and mean.

\section{Research Findings}

\subsection{Respondent Demographics}

The study involved 1000 students of Bachelor of Education from the Faculty of Education in five public universities ranked as research universities, namely Universiti Kebangsaan Malaysia (UKM), Universiti Malaya (UM), Universiti Sains Malaysia (USM), Universiti Putra Malaysia (UPM) and Universiti Teknologi Malaysia (UTM). Field of study for each university is different and varied. A total of 200 respondents were randomly selected from each university to answer

Table 1. Mean scale and the interpretation.

\begin{tabular}{cc}
\hline Mean Score & Interpretation \\
\hline 1.00 to 2.99 & Faded \\
3.00 to 5.99 & Begin to fade \\
6.00 to 8.99 & Still remain \\
9.00 to 10 & Permanent \\
\hline
\end{tabular}


the questionnaire provided. Of the total respondents, the majority of students' age is 20 to 23 years old from the age range involved which is 19 to 43 years old. Overall demographic information of the respondents is summarized in Table 2 according to the percentage.

Table 2 shows data on the survey respondents based on demographic characteristics of the education students from five research universities in Malaysia which are considered as variables in this study. For the gender variable, a total of 1000 respondents were selected as sample who answered the questionnaire. The findings indicate the gender distribution of the survey respondents consisted of 227 male students and 773 female students. This shows that female students have a higher percentage than male students. More female students are entering the universities and pursue Education course.

For the age distribution of respondents, data analysis shows that the highest percentage of student is at the age of 22, followed by 23, 21 and 20 years old. For students' age of 32, 34, 35, 38 and 43 years old, each has only one student. The findings also showed that the highest distribution is of Malay students which are $82.8 \%$, followed by Bumiputera students (9\%) and $6.4 \%$ of Chinese students and the least is Indians which is $1.6 \%$.

Next, the distributions of students' religion, Muslim students have the highest percentage with the total of 879 people and the lowest percentage is of Hindus, which are only 13 people. While the Buddhists and Christian's students are 49 and 59 respectively. For the field of study involved, the highest percentage is of Special Education at 23.3\%, while the second highest is Technology stream students with a total of $16.1 \%$ and the third highest is TESL students which is $15 \%$. Other field of studies is Sports $8.5 \%$, Guidance and Counselling 7.5\%, Islamic Studies 7.2\%, Early Childhood Education 4.6\%, Literature 4.1\% Science 3.6\%, Bahasa Melayu 3.5\%, and the lowest is in the field of Agricultural Sciences and Home Science with a percentage of $3.3 \%$ each. Overall, the field of study involved is 12 .

\subsection{Malay Language Identity}

This section discusses the level of identity of 1000 education students from five Public University ranked as research university. The language identity in this study refers to the mastery of Malay Language among education students. This language identity will be discussed in three aspects, which are understanding, appreciation and practice. The extent to which education student's identity remains strong or fading in terms of understanding, appreciation and practice of the Malay language or vice versa will be discussed in this section.

\subsection{Level of Understanding of Malay Language Identity of Public University Students}

Table 3 discusses the students' understanding of their identity about the Malay language. Analysis shows that the education students' identity still remains. They realize the importance of Malay language as the national language, the language 
Table 2. Distribution of respondents according to the variable of frequency of respondents who answered $(\mathrm{n})=1000$ students.

\begin{tabular}{|c|c|c|c|c|}
\hline \multirow{2}{*}{$\begin{array}{c}\text { No. } \\
1\end{array}$} & \multicolumn{2}{|c|}{ Category } & \multirow{2}{*}{$\begin{array}{c}\text { Frequency }(\mathrm{N}) \\
227\end{array}$} & \multirow{2}{*}{$\begin{array}{c}\text { Percentage (\%) } \\
22.7\end{array}$} \\
\hline & Gender & Male & & \\
\hline & & Female & 773 & 77.3 \\
\hline \multirow[t]{15}{*}{2} & Age & 19 & 7 & .7 \\
\hline & & 20 & 139 & 13.9 \\
\hline & & 21 & 223 & 22.3 \\
\hline & & 22 & 270 & 27.0 \\
\hline & & 23 & 244 & 24.4 \\
\hline & & 24 & 63 & 6.3 \\
\hline & & 25 & 23 & 2.3 \\
\hline & & 26 & 18 & 1.8 \\
\hline & & 27 & 5 & .5 \\
\hline & & 30 & 3 & .3 \\
\hline & & 32 & 1 & .1 \\
\hline & & 34 & 1 & .1 \\
\hline & & 35 & 1 & .1 \\
\hline & & 38 & 1 & .1 \\
\hline & & 43 & 1 & .1 \\
\hline \multirow[t]{5}{*}{3} & Race & Malay & 828 & 82.8 \\
\hline & & Chinese & 64 & 6.4 \\
\hline & & Indian & 16 & 1.6 \\
\hline & & Bumiputera & 90 & 9.0 \\
\hline & & Others & 2 & .2 \\
\hline \multirow[t]{4}{*}{4} & Religion & Islam & 879 & 87.9 \\
\hline & & Buddha & 49 & 4.9 \\
\hline & & Christian & 59 & 5.9 \\
\hline & & Hindu & 13 & 1.3 \\
\hline \multirow[t]{4}{*}{5} & Year of studies & 1 & 356 & 35.6 \\
\hline & & 2 & 411 & 41.1 \\
\hline & & 3 & 156 & 15.6 \\
\hline & & 4 & 77 & 7.7 \\
\hline \multirow[t]{12}{*}{6} & Field of studies & Sports & 85 & 8.5 \\
\hline & & Special ed. & 233 & 23.3 \\
\hline & & TESL & 150 & 15.0 \\
\hline & & Science & 36 & 3.6 \\
\hline & & Art & 41 & 4.1 \\
\hline & & Technology & 161 & 16.1 \\
\hline & & Early chilhood ed. & 46 & 4.6 \\
\hline & & G\&C & 75 & 7.5 \\
\hline & & Islamic Stu. & 72 & 7.2 \\
\hline & & Agricultural Sc. & 33 & 3.3 \\
\hline & & Home Sc. & 33 & 3.3 \\
\hline & & Bah. Melayu & 35 & 3.5 \\
\hline
\end{tabular}


Table 3. Level of understanding of Malay language identity of public university students.

\begin{tabular}{|c|c|c|c|c|c|c|}
\hline \multirow[b]{2}{*}{ Understanding of Language } & \multicolumn{4}{|c|}{ Scale(Percentage) } & \multirow[b]{2}{*}{ Mean } & \multirow{2}{*}{$\begin{array}{c}\text { Interpretation of Mean } \\
\text { Level }\end{array}$} \\
\hline & Faded (1-2) & $\begin{array}{l}\text { Begin to fade } \\
\quad(3-5)\end{array}$ & $\begin{array}{l}\text { Still remain } \\
\quad(6-8)\end{array}$ & $\begin{array}{l}\text { Permanent } \\
\quad(9-10)\end{array}$ & & \\
\hline $\begin{array}{l}\text { D1. Understand the position of the Malay } \\
\text { language as the national language of } \\
\text { Malaysia }\end{array}$ & - & $\begin{array}{l}0.3 \% \\
(3)\end{array}$ & $\begin{array}{r}9.0 \% \\
(90)\end{array}$ & $\begin{array}{c}90.7 \% \\
(907)\end{array}$ & 9.60 & Permanent \\
\hline $\begin{array}{l}\text { D2. Understand the position of the Malay } \\
\text { language as the official language in the } \\
\text { country's administration }\end{array}$ & - & $\begin{array}{l}0.5 \% \\
(5)\end{array}$ & $\begin{array}{l}9.7 \% \\
(97)\end{array}$ & $\begin{array}{c}89.8 \% \\
(898)\end{array}$ & 9.56 & Permanent \\
\hline $\begin{array}{l}\text { D3. Understand the position of the Malay } \\
\text { language as the language of } \\
\text { knowledge/language of instruction in all } \\
\text { levels of education }\end{array}$ & $\begin{array}{l}0.2 \% \\
(2)\end{array}$ & $\begin{array}{c}0.6 \% \\
(6)\end{array}$ & $\begin{array}{l}11.6 \% \\
(116)\end{array}$ & $\begin{array}{c}87.6 \% \\
(876)\end{array}$ & 9.49 & Permanent \\
\hline $\begin{array}{l}\text { D4. Understand the position of the Malay } \\
\text { language as the language of unity among } \\
\text { people of various races }\end{array}$ & $\begin{array}{c}0.3 \% \\
(3)\end{array}$ & $\begin{array}{l}1.0 \% \\
(10)\end{array}$ & $\begin{array}{c}10.1 \% \\
(101)\end{array}$ & $\begin{array}{c}88.6 \% \\
(886)\end{array}$ & 9.48 & Permanent \\
\hline $\begin{array}{l}\text { D5. Knowing that all Malaysians must master } \\
\text { the Malay language proficiently }\end{array}$ & $\begin{array}{l}0.2 \% \\
(2)\end{array}$ & $\begin{array}{l}0.7 \% \\
(7)\end{array}$ & $\begin{array}{l}11.5 \% \\
(115)\end{array}$ & $\begin{array}{c}87.6 \% \\
(876)\end{array}$ & 9.47 & Permanent \\
\hline $\begin{array}{l}\text { D6. Understand that only the Malay language } \\
\text { could unite Malaysians of different races, } \\
\text { languages and religions }\end{array}$ & $\begin{array}{l}0.9 \% \\
(9)\end{array}$ & $\begin{array}{l}3.1 \% \\
(31)\end{array}$ & $\begin{array}{l}11.9 \% \\
(119)\end{array}$ & $\begin{array}{l}81.1 \% \\
(811)\end{array}$ & 9.18 & Permanent \\
\hline $\begin{array}{l}\text { D7. Understand that Malay language have same } \\
\text { status as other foreign language (English) }\end{array}$ & $\begin{array}{l}1.7 \% \\
(17)\end{array}$ & $\begin{array}{c}3.5 \% \\
(35)\end{array}$ & $\begin{array}{l}18.9 \% \\
(189)\end{array}$ & $\begin{array}{c}75.9 \% \\
(759)\end{array}$ & 8.96 & Still Remain \\
\hline $\begin{array}{l}\text { D8. Understand that mastering the Malay } \\
\text { language can help me get a job }\end{array}$ & $\begin{array}{l}1.7 \% \\
(17)\end{array}$ & $\begin{array}{c}3.4 \% \\
(34)\end{array}$ & $\begin{array}{c}21.1 \% \\
(211)\end{array}$ & $\begin{array}{c}73.8 \% \\
(738)\end{array}$ & 8.93 & Still Remain \\
\hline $\begin{array}{l}\text { D9. Understand that mastering the Malay } \\
\text { language can help me further my education }\end{array}$ & $\begin{array}{l}1.5 \% \\
(15)\end{array}$ & $\begin{array}{r}3.8 \% \\
(38)\end{array}$ & $\begin{array}{c}21.5 \% \\
(215)\end{array}$ & $\begin{array}{c}73.2 \% \\
(732)\end{array}$ & 8.93 & Still Remain \\
\hline $\begin{array}{l}\text { D10.Understand that mastering Malay language } \\
\text { can help me communicate with friends of } \\
\text { various races }\end{array}$ & $\begin{array}{l}1.3 \% \\
(13)\end{array}$ & $\begin{array}{r}2.5 \% \\
(25)\end{array}$ & $\begin{array}{l}19.1 \% \\
(191)\end{array}$ & $\begin{array}{c}77.1 \% \\
(771)\end{array}$ & 9.06 & Permanent \\
\hline $\begin{array}{l}\text { D11.Know that Malay language can be used in } \\
\text { all fields of knowledge }\end{array}$ & $\begin{array}{l}1.9 \% \\
(19)\end{array}$ & $\begin{array}{l}4.8 \% \\
(48)\end{array}$ & $\begin{array}{c}18.0 \% \\
(180)\end{array}$ & $\begin{array}{c}75.3 \% \\
(753)\end{array}$ & 8.89 & Still Remain \\
\hline \multicolumn{5}{|c|}{ Overall Mean of Understanding of Malay Language } & 9.23 & Permanent Identity \\
\hline
\end{tabular}

of knowledge and unity in the context of education in Malaysia. Students will also understand the position of Malay language as the language of instruction in Malaysia's education system. The overall mean is 9.23 , which means that the level of understanding of Malay identity is permanent. The average mean is between 8.93 (item D9) to 9.60 (items D1). Although there are some items which obtain the mean level of still remain, this does not mean that the identity of education students have already started to fade. This can be summarized that the students:

1) Understand the position of the Malay language as the national language, official language, the language of instruction and the language of unity in Malaysia.

2) Understanding the importance the Malay language as the language of education in the education system in Malaysia.

3) Understand that mastering the Malay language is as important as English proficiency. 
4) Understand that proficiency of the Malay language can help them get a job, further their studies, help them communicate and mastering various fields of knowledge.

\subsection{Level of Appreciation of Malay Language Identity among Public University Students}

Table 4 discusses aspects of Malay identity in terms of appreciation. In terms language identity from the aspect of appreciation, the overall mean obtained is 8.99, which means that the identity is at the level of still remain. This means that the appreciation of Malay language identity among education students have a lot of things that should be consolidated and strengthened. There are also a number of education students in which their appreciation of the Malay language is faded or began to fade. Although the still remain identity is associated with universities and government measures that wants students to be proficient in English as well as Malay language, then it is not an excuse for students to not appreciate Malay language as the language of knowledge. The average mean of appreciation of language are between 8.38 (item D17) to 9.32 (item D19). This can be summarizes that the students:

Table 4. Level of understanding of Malay Language identity of Public University students.

\begin{tabular}{|c|c|c|c|c|c|c|}
\hline \multirow[b]{2}{*}{ Appreciation of Language } & \multicolumn{4}{|c|}{ Scale(Percentage) } & \multirow[b]{2}{*}{ Mean } & \multirow{2}{*}{$\begin{array}{l}\text { Interpretation of } \\
\text { Mean Level }\end{array}$} \\
\hline & Faded (1-2) & $\begin{array}{l}\text { Begin to fade } \\
\qquad(3-5)\end{array}$ & $\begin{array}{l}\text { Still remain } \\
(6-8)\end{array}$ & $\begin{array}{l}\text { Permanent } \\
(9-10)\end{array}$ & & \\
\hline $\begin{array}{l}\text { D12. More comfortable speaking in Malay language } \\
\text { than in foreign language }\end{array}$ & $\begin{array}{l}1.3 \% \\
(13)\end{array}$ & $\begin{array}{r}3.8 \% \\
(38)\end{array}$ & $\begin{array}{c}19.8 \% \\
(198)\end{array}$ & $\begin{array}{c}75.1 \% \\
(751)\end{array}$ & 8.98 & Still Remain \\
\hline $\begin{array}{l}\text { D13. Proud to use Malay language } \\
\text { in everyday speech }\end{array}$ & $\begin{array}{c}0.4 \% \\
(4)\end{array}$ & $\begin{array}{c}2.2 \% \\
(22)\end{array}$ & $\begin{array}{c}15.6 \% \\
(156)\end{array}$ & $\begin{array}{c}81.8 \% \\
(818)\end{array}$ & 9.24 & Permanent \\
\hline $\begin{array}{l}\text { D14. Proud to use the Malay language in } \\
\text { everyday writing }\end{array}$ & $\begin{array}{l}0.6 \% \\
(6)\end{array}$ & $\begin{array}{c}2.7 \% \\
(27)\end{array}$ & $\begin{array}{l}17.0 \% \\
(170)\end{array}$ & $\begin{array}{l}79.7 \% \\
(797)\end{array}$ & 9.15 & Permanent \\
\hline $\begin{array}{l}\text { D15. Proud that Malay language be the medium of } \\
\text { communication for the various races in Malaysia }\end{array}$ & $\begin{array}{l}0.7 \% \\
(7)\end{array}$ & $\begin{array}{r}2.3 \% \\
(23)\end{array}$ & $\begin{array}{c}15.5 \% \\
(155)\end{array}$ & $\begin{array}{c}81.5 \% \\
(815)\end{array}$ & 9.24 & Permanent \\
\hline $\begin{array}{l}\text { D16. Realize that a person who love Malay language } \\
\text { will have stronger spirit of unity }\end{array}$ & $\begin{array}{l}1.8 \% \\
(18)\end{array}$ & $\begin{array}{l}4.3 \% \\
(43)\end{array}$ & $\begin{array}{l}17.1 \% \\
(171)\end{array}$ & $\begin{array}{c}76.8 \% \\
(768)\end{array}$ & 8.97 & Still Remain \\
\hline $\begin{array}{l}\text { D17. Believes that Malay language should not mixed } \\
\text { with English when communicating }\end{array}$ & $\begin{array}{c}5.4 \% \\
(54)\end{array}$ & $\begin{array}{c}6.3 \% \\
(63)\end{array}$ & $\begin{array}{l}22.3 \% \\
(223)\end{array}$ & $\begin{array}{c}66.0 \% \\
(660)\end{array}$ & 8.38 & Still Remain \\
\hline $\begin{array}{l}\text { D18. Believes that the Malay language is easier } \\
\text { spoken/learned than English/other languages }\end{array}$ & $\begin{array}{c}2.6 \% \\
(26)\end{array}$ & $\begin{array}{c}5.6 \% \\
(56)\end{array}$ & $\begin{array}{l}16.4 \% \\
(164)\end{array}$ & $\begin{array}{c}75.4 \% \\
(754)\end{array}$ & 8.85 & Still Remain \\
\hline $\begin{array}{l}\text { D19. Believes that the Malay language should be } \\
\text { mastered by all Malaysians }\end{array}$ & $\begin{array}{c}0.6 \% \\
(6)\end{array}$ & $\begin{array}{r}2.0 \% \\
(20)\end{array}$ & $\begin{array}{l}12.6 \% \\
(126)\end{array}$ & $\begin{array}{c}84.8 \% \\
(848)\end{array}$ & 9.32 & Permanent \\
\hline $\begin{array}{l}\text { D20. Believes that Malay language can be used as } \\
\text { an international/ASEAN language }\end{array}$ & $\begin{array}{r}2.3 \% \\
(23)\end{array}$ & $\begin{array}{r}4.8 \% \\
(48)\end{array}$ & $\begin{array}{c}21.3 \% \\
(213)\end{array}$ & $\begin{array}{c}71.6 \% \\
(716)\end{array}$ & 8.79 & Still Remain \\
\hline $\begin{array}{l}\text { D21. Convinced that Malay language can compete with } \\
\text { English/primary language }\end{array}$ & $\begin{array}{r}2.9 \% \\
(29)\end{array}$ & $\begin{array}{c}6.0 \% \\
(60)\end{array}$ & $\begin{array}{l}21.4 \% \\
(214)\end{array}$ & $\begin{array}{c}69.7 \% \\
697)\end{array}$ & 8.66 & Still Remain \\
\hline D22. Convinced that Malay language can unite all races & $\begin{array}{c}0.8 \% \\
(8)\end{array}$ & $\begin{array}{c}3.9 \% \\
(39)\end{array}$ & $\begin{array}{l}15.4 \% \\
(154)\end{array}$ & $\begin{array}{c}79.9 \% \\
(799)\end{array}$ & 9.10 & Permanent \\
\hline $\begin{array}{l}\text { D23. Believe that Malay language } \\
\text { foster racial understanding }\end{array}$ & $\begin{array}{l}0.9 \% \\
(9)\end{array}$ & $\begin{array}{c}3.7 \% \\
(37)\end{array}$ & $\begin{array}{l}15.9 \% \\
(159)\end{array}$ & $\begin{array}{c}79.5 \% \\
(795)\end{array}$ & 9.11 & Permanent \\
\hline $\begin{array}{l}\text { D24. Using the Malay language will make me love my } \\
\text { country more }\end{array}$ & $\begin{array}{c}2.0 \% \\
(20)\end{array}$ & $\begin{array}{l}4.2 \% \\
(42)\end{array}$ & $\begin{array}{l}15.6 \% \\
(156)\end{array}$ & $\begin{array}{c}78.2 \% \\
(782)\end{array}$ & 9.03 & Permanent \\
\hline \multicolumn{5}{|c|}{ Overall Mean of Appreciation of Malay Language } & 8.99 & Identity Still Remain \\
\hline
\end{tabular}


1) Should use of the Malay language in their daily lives, whether in speech or writing.

2) Should appreciate the position of the Malay language as the language of knowledge and unity in Malaysia.

3) Must be proficient in Malay language.

4) Need to be confident in the ability of the Malay language as the language of knowledge and unity in Malaysia.

5) Should master the Malay language well as a sign of love of the motherland.

\subsection{Level of Practice of Malay Language Identity among Public University Students}

Table 5 discusses the practice aspect of Malay language. The overall mean showed that the identity is still remained. Mean obtained was 8.99. This means that education students still need to improve their Malay language proficiency. There are still a lot of education students in the Public University which their practice of Malay language is faded and began to fade. Students begin to give priority to English proficiency. This is to some extent eroded the students' Malay language identity. The average mean is between 7.78 (item D36) to 0.33 (item D33). The average mean of still remain suggests that the practice of Malay language identity among education stream students should be given attention and

Table 5. Level of practice of Malay Language identity of Public University students.

\begin{tabular}{|c|c|c|c|c|c|c|}
\hline \multirow{2}{*}{$\begin{array}{l}\text { Practice of } \\
\text { Language }\end{array}$} & \multicolumn{4}{|c|}{ Scale(Percentage) } & \multirow{2}{*}{ Mean } & \multirow{2}{*}{$\begin{array}{c}\text { Interpretation of Mean } \\
\text { Level }\end{array}$} \\
\hline & Faded (1-2) & $\begin{array}{l}\text { Begin to fade } \\
\quad(3-5)\end{array}$ & $\begin{array}{l}\text { Still remain } \\
\quad(6-8)\end{array}$ & $\begin{array}{l}\text { Permanent } \\
\quad(9-10)\end{array}$ & & \\
\hline $\begin{array}{l}\text { D25. Fully use Malay language in the } \\
\text { teaching/learning }\end{array}$ & $\begin{array}{c}5.8 \% \\
(58)\end{array}$ & $\begin{array}{l}6.6 \% \\
(66)\end{array}$ & $\begin{array}{c}23.1 \% \\
(231)\end{array}$ & $\begin{array}{c}64.5 \% \\
(645)\end{array}$ & 8.31 & Still Remain \\
\hline $\begin{array}{l}\text { D26. Do not use mixed languages in daily } \\
\text { communication and teaching/learning }\end{array}$ & $\begin{array}{c}6.7 \% \\
(67)\end{array}$ & $\begin{array}{c}9.0 \% \\
(90)\end{array}$ & $\begin{array}{c}25.4 \% \\
(254)\end{array}$ & $\begin{array}{c}58.9 \% \\
(589)\end{array}$ & 8.03 & Still Remain \\
\hline D27. Using polite Malay when speaking & $\begin{array}{c}0.9 \% \\
(9)\end{array}$ & $\begin{array}{c}3.1 \% \\
(31)\end{array}$ & $\begin{array}{l}15.7 \% \\
(157)\end{array}$ & $\begin{array}{c}80.3 \% \\
(803)\end{array}$ & 9.15 & Permanent \\
\hline $\begin{array}{l}\text { D28. Using the accurate/correct Malay Language } \\
\text { when writing }\end{array}$ & $\begin{array}{c}0.4 \% \\
(4)\end{array}$ & $\begin{array}{c}2.1 \% \\
(21)\end{array}$ & $\begin{array}{c}21.5 \% \\
(215)\end{array}$ & $\begin{array}{c}76.0 \% \\
(760)\end{array}$ & 9.09 & Permanent \\
\hline $\begin{array}{l}\text { D29. Trying to improve the quality oral/speaking } \\
\text { proficiency of Malay Language }\end{array}$ & $\begin{array}{c}0.4 \% \\
(4)\end{array}$ & $\begin{array}{c}2.0 \% \\
(20)\end{array}$ & $\begin{array}{c}18.6 \% \\
(186)\end{array}$ & $\begin{array}{c}79.0 \% \\
(790)\end{array}$ & 9.18 & Permanent \\
\hline $\begin{array}{l}\text { D30. Trying to improve reading proficiency in } \\
\text { Malay Language }\end{array}$ & $\begin{array}{c}0.4 \% \\
(4)\end{array}$ & $\begin{array}{c}1.8 \% \\
(18)\end{array}$ & $\begin{array}{c}18.2 \% \\
(182)\end{array}$ & $\begin{array}{c}79.6 \% \\
(796)\end{array}$ & 9.20 & Permanent \\
\hline $\begin{array}{l}\text { D31. Trying to improve writing proficiency in } \\
\text { Malay Language }\end{array}$ & $\begin{array}{l}0.5 \% \\
(5)\end{array}$ & $\begin{array}{c}2.0 \% \\
(20)\end{array}$ & $\begin{array}{l}18.4 \% \\
(184)\end{array}$ & $\begin{array}{c}79.1 \% \\
(791)\end{array}$ & 9.18 & Permanent \\
\hline $\begin{array}{l}\text { D32. Using the proper/formal Malay Language } \\
\text { in formal situations }\end{array}$ & $\begin{array}{l}0.5 \% \\
(5)\end{array}$ & $\begin{array}{l}1.3 \% \\
(13)\end{array}$ & $\begin{array}{c}16.8 \% \\
(168)\end{array}$ & $\begin{array}{c}81.4 \% \\
(814)\end{array}$ & 9.18 & Permanent \\
\hline $\begin{array}{l}\text { D33. Using the proper/formal Malay Language } \\
\text { in informal situations }\end{array}$ & $\begin{array}{c}2.7 \% \\
(27)\end{array}$ & $\begin{array}{c}5.7 \% \\
(57)\end{array}$ & $\begin{array}{c}23.9 \% \\
(239)\end{array}$ & $\begin{array}{c}67.7 \% \\
(667)\end{array}$ & 9.22 & Permanent \\
\hline $\begin{array}{l}\text { D34. Watch the broadcast in Malay compared to } \\
\text { broadcasts in other languages }\end{array}$ & $\begin{array}{l}4.9 \% \\
(49)\end{array}$ & $\begin{array}{c}9.6 \% \\
(96)\end{array}$ & $\begin{array}{c}24.2 \% \\
(242)\end{array}$ & $\begin{array}{c}61.3 \% \\
(613)\end{array}$ & 8.60 & Still Remain \\
\hline $\begin{array}{l}\text { D35. Explore and find material on the Internet } \\
\text { in Malay }\end{array}$ & $\begin{array}{l}4.2 \% \\
(42)\end{array}$ & $\begin{array}{c}8.6 \% \\
(86)\end{array}$ & $\begin{array}{c}24.5 \% \\
(245)\end{array}$ & $\begin{array}{c}62.7 \% \\
(627)\end{array}$ & 8.13 & Still Remain \\
\hline $\begin{array}{l}\text { D36. Do not use mixed language/abbreviation in } \\
\text { social media }\end{array}$ & $\begin{array}{c}7.9 \% \\
(79)\end{array}$ & $\begin{array}{c}11.5 \% \\
(115)\end{array}$ & $\begin{array}{c}25.3 \% \\
(253)\end{array}$ & $\begin{array}{c}55.3 \% \\
(553)\end{array}$ & 7.78 & Still Remain \\
\hline \multicolumn{5}{|c|}{ Overall Mean of Practice of Malay Language } & 8.99 & Identity Still Remain \\
\hline
\end{tabular}


properly addressed by the Public University. This can be summarizes that the students:

1) Should fully use Malay language in teaching, learning, communicating/speaking and writing.

2) Need to use formal and correct Malay language is formal and informal situations.

3) Should strive to master and practice the correct use of Malay language in formal and informal situations.

4) Do not mix up the Malay language with abbreviation that can affect the position of the Malay language as the language of knowledge.

\subsection{Summary of Comparison of Understanding, Appreciation and Practicing Aspect of Malay Language among Public University Students}

Based on Table 6 and Figure 1, it can be concluded that there are different levels of understanding, appreciation and practice of Malay language among students

Table 6. Summary of comparisons of understanding, appreciation and practice among Public University students.

\begin{tabular}{|c|c|c|c|c|}
\hline No. & Malay Language Identity & Aspect & Mean & Interpretation of Identity Level \\
\hline \multirow[t]{4}{*}{1} & UKM & Understanding & 9.33 & Permanent \\
\hline & & Appreciation & 8.73 & Still remain \\
\hline & & Practice & 8.74 & Still remain \\
\hline & & Total & 8.93 & Still remain \\
\hline \multirow[t]{4}{*}{2} & UPM & Understanding & 9.18 & Permanent \\
\hline & & Appreciation & 9.10 & Permanent \\
\hline & & Practice & 8.71 & Still remain \\
\hline & & Total & 9.00 & Permanent \\
\hline \multirow[t]{4}{*}{3} & UM & Understanding & 8.86 & Still remain \\
\hline & & Appreciation & 8.45 & Still remain \\
\hline & & Practice & 8.24 & Still remain \\
\hline & & Total & 8.57 & Still remain \\
\hline \multirow[t]{4}{*}{4} & USM & Understanding & 9.48 & Permanent \\
\hline & & Appreciation & 9.36 & Permanent \\
\hline & & Practice & 9.15 & Permanent \\
\hline & & Total & 9.33 & Permanent \\
\hline \multirow[t]{5}{*}{5} & UTM & Understanding & 9.29 & Permanent \\
\hline & & Appreciation & 9.04 & Permanent \\
\hline & & Practice & 8.56 & Still remain \\
\hline & & Total & 8.96 & Still remain \\
\hline & & Total Mean & 8.96 & Identity Still Remain \\
\hline
\end{tabular}




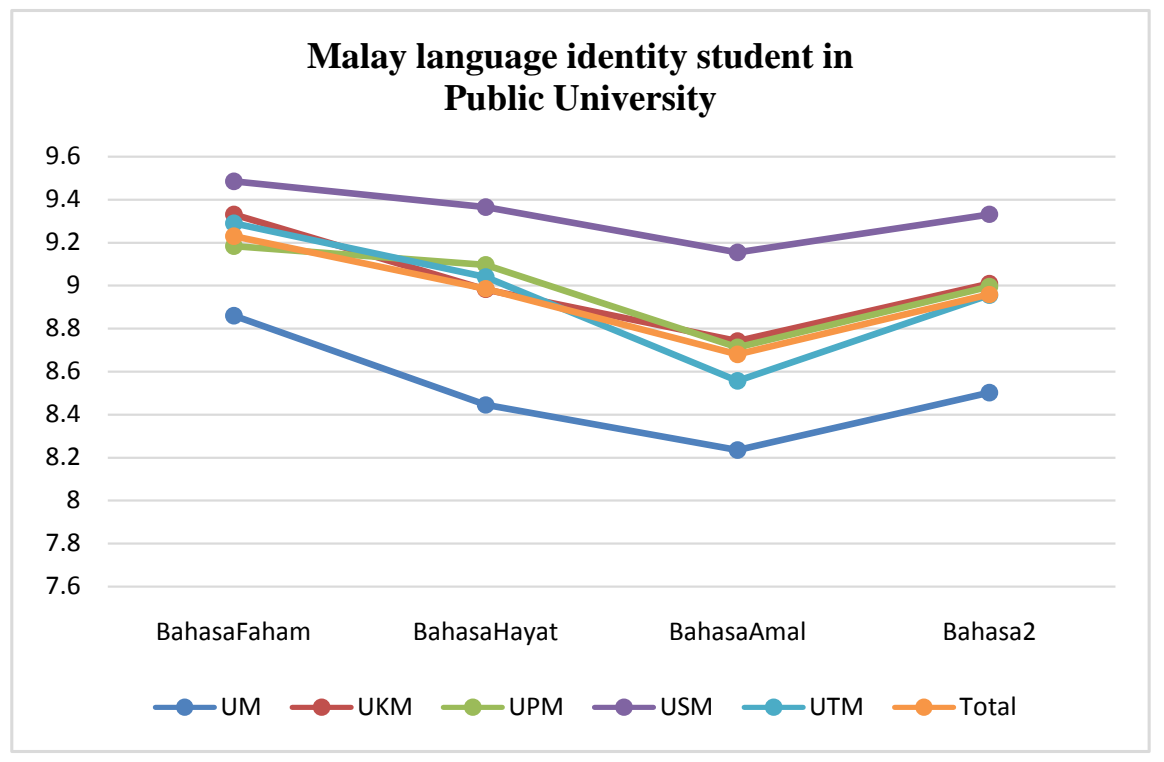

Figure 1. Comparison of mean values of Malay language identity of the education stream students according to the Public University.

of education at five public universities studied. The overall mean is 8.96, which means that the identity is still remained. This means that the education stream students are still able to understand, appreciate and practice the use of Malay language in teaching. The conclusions that can be made here is:

1) UM student is the lowest education students compared to UKM, UPM, USM and UTM students in terms of understanding, appreciation and practice of Malay language.

2) USM students are the education students which are highest in terms of the understanding, appreciation and practice of Malay language compared to students in UKM, UPM, UM and UTM.

3) The practice aspect is found to be the lowest identity compared to understanding and appreciation aspects among all public universities studied. UKM, UPM, UM and UTM students is lacking in their Malay language practice. Nevertheless, the overall mean is still on the level of still remains identity.

\section{Discussions}

Identity of the teacher is very important to be nurtured because balance and harmonic students in terms of physical, emotional, spiritual and intellectual (JERI) will be resulted from the influence of teachers' attitudes and behavior in teaching and learning in the classroom. Identity is determined by seven key elements studied. Overall, the results of survey on the Malay language identity of the education students in the Faculty of Education at five public universities shows the level of students' identity remains at the level of permanent. This shows that the students have a correct level of understanding, appreciation and practice of the use of Malay language during learning and life. This finding is consistent with the studies of Zamri et al. (2016) which found that students of 
the Faculty of Education UKM have a high level of identity including the aspect of Malay language.

This finding differs from findings by Hashim (2008) which examines the identity of Malay students. Although the finding stated that identity of the students is still permanent in the religion, knowledge, and educate aspects but from the aspect of value it is found that the identity of the students had begun to fade. If you look at the understanding, appreciation and practice construct of the value aspects, the findings demonstrate that an understanding and appreciation of value among students is lower compared to value practice This finding are equivalent to study of Ramlah (2005), Singh (2013) and Hashim (2008) who stated that most of the students of Public University is still have strong understanding, appreciation and practice of their identity.

In addition, the decreasing appreciation of the use of the Malay language compared to understanding and appreciation aspects is related to the emphasis of the use of English in teaching and learning activities in most public universities. According to Siti Rahimah et al. (2014), mastery of the language identity confusion led to chaos in Malay language proficiency level of students. Focusing more on English makes the identity of the national language fades. Similar results were found in Siti Sarah (2015) and Hashim (2008) studies.

In conclusion, the identity of education student in UKM, UPM, UM, USM and UTM still remained in seven aspects studied in terms of their Malay language. Understanding, appreciation and practice of language, culture identity is still at a high level of, which means that they still retain the use of the Malay language in learning and life. Their identity remained despite a slight reduction in the understanding, appreciation and practice in terms of language identity.

\section{Conclusion}

Based on these findings, it is clearly showed that it is important to emphasize and nurture this element of identity in the students who will become teachers for the next generation to ensure the betterment of the country's education. With these elements fostered, the prospective teachers will have the best personality and can be role models to the next generation and the result is the birth of harmonious and developing countries and causing less social problems and less effects of globalization.

In conclusion, attention and emphasis of the use of English to some extent affect the role of Malay language as the language of knowledge at the Public University studied. As a future teacher, the students should have excellent command of Malay language. At the same time, they also have English proficiency. This way we can uphold the Malay language and strengthen the English language.

\section{References}

Abdul Latiff, A. B. (2012). Jati diri dan patriotisme berpaksikan sejarah, perlembagaan dan dasar kerjaaan. [Identity and Patriotism Are Based on History, Constitution and Government Policy.] In A. B. Abdul Latif, H. MohdYusof, W. Y. Wan Zaidah, \& A. R. 
Asiah (Eds.), Jati diri dan patriotisme teras peradaban Malaysia [The Identity and Patriotism of Malaysian Civilization], Institusi Peradaban Melayu Press, Universiti Pendidikan Sultan Idris Press, Tanjung Malim, 1-34.

Tarmizi, A. (2013). Kajian toleransi sosio-agama di Semenanjung Malaysia. [The Study of Socio-Religoius Tolerance in Peninsular Malaysia.] Institut Kajian dan Latihan Integrasi Nasional. Jurnal Perpaduan, 138-170.

Hashim, M. (2008). Hati budi Melayu: Pengukuhan menghadapi cabaran abad ke-21. [Social Character Malay Trait: Strengthening the Challenge of the 21st Century.] Universiti Putra Malaysia Press, Serdang, Malaysia.

Ismail, B. (2010). Sejarah kepimpinan dan politik ke arah pembentukan jati diri kebangsaan. [History of Leadership and Politicstowardstheformation of National Identiti.] In O. Mohd Yusof (Ed.), Jati diri kebangsaan manhaj Islam hadhari [National Identity of manhaj Islam hadhari], Penerbitan Institut Islam Hadhari Press, Universiti Kebangsaan Malaysia, Bangi, Malaysia, 197-120.

Kementerian Belia dan Sukan [Ministry Youth and Sports] (2011). Indeks Belia Malaysia 2011. [Malaysia Indexing Youth.] Institut Penyelidikan dan Pembangunan Belia Malaysia Press, Putrajaya, Malaysia.

Kementerian Pendidikan Malaysia [Malaysia Ministry of Education] (2013). Pelan Pembangunan Pendidikan Malaysia 2013-2025. [Malaysia Education Development Pelan 2013-2025.] Bahagian Pembangunan Kurikulum Press, Putrajaya, Malaysia.

Mohd Isa, H., Mohd. Aliff, M. N., Jamil, A., Ab Halim, T., Amirah, I., Nurul Pasihah, H. \& Siti Syazwani, S. (2012). Keberkesanan pertubuhan belia dalam menyemai jati diri Islam. [The Effectiveness Youth Society in Islamic Sowing Identity.] Malaysian Journal of Youth Studies, 7, 93-104.

Mohd Yusof, O. et al. (2012). Jati diri kebangsaan dalam kalangan pelajar IPT. [National Identity among Higher Education Institute Students.] Jurnal Hadhari Special Edition, 67-78.

Mutsalim, K. \& Jaffary, A. (2014). Toleransi beragama \& implikasinya dalam kalangan mahasiswa/i Muslim dan Buddha di Prince of Songkhla University, Thailand. [The Religious Tolerance and the Implication between Muslim/Buddha Student in Prince of Songhla University, Thailand.] Journal of Islamic and Arabic Education, 5, 1-14.

Piaw, C. Y. (2012). Asas statistik penyelidikan. Edisi ke-2. [Basic Statistic in Research (2nd ed.).] Kuala Lumpur: Mc Graw-Hill (M).

Ramlah, A. (2005). Kajian tahap pemahaman, penghayatan dan pengamalan Rukun Negara di kalangan pelajar IPT. [The Study of Level Understanding, Appreciation and Practice Rukun Negara among Higher Education Institute Students.] Geran Penyelidikan. [Research Grant.] Jabatan Perpaduan Negara dan Integriti Nasional Press, Kuala Lumpur.

Salmah, H. (2005). Pemahaman konsep pembinaan jati diri negara bangsa dalam mata pelajaran Sejarah KBSM Tingkatan Lima di daerah Keluang. [The Understanding Concept of National Identity in Form Five Kbsm History Subject in Keluang District.] Master Dissertation, Fakulti Pendidikan, Universiti Kebangsaan Malaysia, Bangi, Malaysia.

Singh, S. (2013). Kajian pemahaman, penghayatan dan pengamalan Rukun Negara dalam kalangan belia Malaysia. [The Study of Understanding, Appreciation and Practice Rukun Negara among Malaysia Youth.] Jurnal Perpaduan Institut Kajian dan Latihan Integrasi Nasional, 1, 89-137.

Siti Rahimah, M., Raja Masittah, R. A. \& Normahdiah, S. S. (2014). Kekeliruan jati diri punca bahasa bercampur aduk. [The Confusion of Mixed Language.] Jurnal Bahasa, 14, 
134-158.

Siti Sarah, A. K. (2015). Pembinaan alat pengukuran hati budi Melayu. [Development of Malay Identity Instrument.] Doctoral Dissertation, Fakulti Bahasa Moden dan Komunikasi, Universiti Putra Malaysia, Serdang, Malaysia.

Zamri, M., Nik Mohd Rahimi, N. Y., Mohd Mahzan, A., Chew, F. P. \& Ummu Taqiah, B. (2016). Pemahamam, penghayatan dan pengamalan jati diri pelajar Fakulti Pendidikan, Universti Kebangsaan Malaysia. [The Understanding, Appreciation and Practice Identity among Student of Faculty of Education, Universiti Kebangsaan Malaysia.] Project Paper Presented at the 4th International Conference Asean Comparative Education Research Network (ACERN), 31 November - 1 Disember 2016, Grand Inna Muara Hotel, Padang, Sumatera Barat. Under Universitas Ekasakti, Padang and Fakulty of Education, Universiti Kebangsaan Malaysia, Bangi, Malaysia. 